\title{
Theory of Planned Behavior on the Determinant of Participation in the Long-Term Contraceptive Method among Women of Reproductive Age, in Nganjuk, East Java
}

\author{
Joeliatin'), Bhisma Murti²), Nunuk Suryani3) \\ ${ }^{1)}$ School of Midwifery, AKBID Wiyata Mitra Husada, Kertosono, Nganjuk, East Java \\ 2) Faculty of Medicine, Universitas Sebelas Maret \\ 3)Faculty of Teaching and Educational Sciences, Universitas Sebelas Maret
}

\begin{abstract}
Background: Unintended pregnancies remain a substantial global public health issue despite considerable advances in contraceptive technologies. The global trend shows that the use of permanent contraception to prevent unintended pregnancy is high. Although the trend also shows a rise in the use of long-acting reversible methods, these are still underutilized despite having contraceptive as well as non-contraceptive benefits. This study aimed to examine the determinants of participation in long-term contraceptive method among women of reproductive age in Nganjuk, East Java, using Theory of Planned Behavior.

Subjects and Method: This was an analytic observationalstudy, using case control design. This study was conducted in Bagor, Nganjuk, East Java.A total of 100 women of reproductive age was selected for this study byfixed disease sampling. The independent variables wereconstructs in the Theory of Planned Behavior, i.e. attitude, subjective norm, andperceived behavior control. The dependent variables wereintention and participation in long-term contraceptive use.The data were collected by a set of questionnaire, and analyzed by path analysis.

Results: Intention had direct and positive effect on participation in long-term contraceptive use $(\mathrm{b}=2.07$; CI 95\%=0.78 to 3.36; $\mathrm{p}=0.002)$, attitude ( $\mathrm{b}=1.40$; CI 95\%=0.41 to $2.40 \mathrm{p}=0.006)$, subjective norm $(\mathrm{b}=1.64 ; \mathrm{CI} 95 \%=0.76$ to $2.53 ; \mathrm{p}<0.001)$, and perceived behavior control $(\mathrm{b}=1.22 ; \mathrm{CI}$ $95 \%=0.32$ to $2.12 ; \mathrm{p}=0.008$ ) had indirect positive effect on participation in long-term contraceptive use through intention.

Conclusion: There are direct and indirect effect of Theory of Planned Behavior constructs on participation long-term contraceptive use among women of reproductive age.
\end{abstract}

Keywords: Theory of Planned Behavior, long-term contraceptive method, reproductive age

\section{Correspondence:}

Joeliatin. School of Midwifery, AKBID Wiyata Mitra Husada, Kertosono, Nganjuk, East Java. Email: yulisuyitno77@gmail.com.$$
\text { BACKGROUND }
$$

Indonesia is one of the most populous countries in the world.Indonesia population is ranked4th in the world, after PRC, India, and USA. The total number of Indonesia population in 2010 was 237.6 million people with annual growth rates by $1.49 \%$ (Central Bureau of Statistic, 2012). The large number of population in Indonesia is the potential human resources. Its growth and distribution need to be managed and
\end{abstract}

regulated, so burden of national problems does not occur. One of the effective efforts in controlling the population growth rate in Indonesia is through the Family Planning and Birth Control for couples of reproductive age, especially women of reproductive age.

The Family Planning and Birth Control is manifested in the form of contraceptive use for effective fertility control. All methods or contraceptives are provided and offered to the community, in order to 
give optimal benefits by minimizing side effects and complaints. A variety of contraceptives which have been widely known in the community are pills, injections, IUDs, implants, and permanent contraception such as tubectomy for women and vasectomy for men. The number of contraceptive use has increased from $57.4 \%$ in 1997 to 60.3\% in 2003.

Target of BKKBN (National Population and Family Planning Board in 2014 is the achievement of the Long-Term Contraceptive Method (LTCM) of new Family Planning participants by $65 \%$. However, based on the report of FPBC by BKKBN, the results of Family Planning services until the period of April 2014 showed that the majority of new Family Planning participants were still dominated by Non-LTCM by 81.86\% from all new Family Planning participants. Meanwhile, the new Family Planning participants who used the LTCM were only $18.14 \%$. Injection and contraceptive pill were the most popular FPBC methods with more than $70 \%$ of new FPBCparticipants (BKKBN, 2007).

The use of contraceptive for the new Family Planning participants in Nganjuk Regency in 2015 was also still dominated by Non-LTCM by $72 \%$, while the LTCM was 28\% (Nganjuk Health Office, 2016). The participation of couples of reproductive age in Family Planning in Bagor District, Nganjuk Regency is still dominated by the NonLTCM group. The Family Planning is less effective due to non-LTCM failure rates, especially injection and pill contraception which are still high (2-8\%). As a result, the goal of Norma Keluarga Kecil Bahagia Sejahtera (Prosperous and Happy Small Family) is hampered. The current number of health workers who are able to handle participants in the LTCM is small. It affects the high usage of non-LTCM contraception. Another factors are the lack of public know- ledge about the effectiveness of LTCM and the cost of LTCM services which are relatively more expensive. Therefore, an indepth study of the factors which influence the participation of couples of reproductive age needs to be carried out, especially the reproductive age in LTCM in Bagor Community Health Center working area. Therefore, an overview and analysis of the problems are obtained and treatment can be conducted.

The scientific approach which can be implemented to examine these problems is Theory of Planned Behavior (TPB). This approach can identify motivational effects on behavior outside the individual and direct strategies for changing people's behavior through measurement of attitude, subjective norms, and perceived behavioral control factors. These three factors will influence intention of a person to adopt a behavior, so that the desired behavior can be obtained. Therefore, through the TPB approach, the researcher intended to analyze the effects of attitude, subjective norms, and perceived behavioral control factors on the intention and participation of women of reproductive age in LTCM.

The purpose of this study was the implementation of the Theory of Planned Behavior (TPB) of women of reproductive age participation in LTCM in Bagor Community Health Center, Nganjuk, East Java, using path analysis.

\footnotetext{
SUBJECTS AND METHOD

This was an analytic observational study, using case control design. This study was conducted in August - September 2016 at Bagor Community Health Center, Nganjuk. The study variables were attitude, subjective norm, perceived behavior control, intention, and participation in Long-Term Contraceptive Method. The source population of this study was women of reproduc-
} 
Journal of Health Promotion and Behavior (2016), 1(3): 172-180

https://doi.org/10.26911/thejhpb.2016.01.03.04

tive age in the working area of Bagor Community Health center, Nganjuk. A total of 100 women of reproductive age was selected for this study by fixed disease sampling, with 1:3 ratio between diseased group (case) and non-diseased groups (control). The data were collected by a set of questionnaire and analyzed by path analysis.

\section{RESULTS}

\section{Sample characteristics}

The results of the study were obtained by ceptive Method (case group) and 75 participants in the non-Long-Term Contraceptive Method (control group). Based on table 1, most of mothers in case group were >35 years of age (20 respondents), had an education $\geq$ Senior High School (25 respondents), housewives (10 respondents), had $\geq 3$ children (12 respondents), had normal labor history (25 respondents), had age of menarche of 12-15 years (16 respondents), and received information (25 respondents).

25 participants in the Long-Term Contra-

Table 1. The characteristics of subjects of the study based on maternal age, maternal education, maternal occupation, number of children, maternal labor, age of menarche and information acquisition

\begin{tabular}{|c|c|c|c|c|c|}
\hline \multirow{2}{*}{ Characteristic } & \multicolumn{2}{|c|}{ Case } & \multicolumn{2}{|c|}{ Control } & \multirow{2}{*}{$\mathbf{p}$} \\
\hline & $\mathbf{n}$ & $\%$ & $\mathbf{n}$ & $\%$ & \\
\hline \multicolumn{6}{|l|}{ Maternal Age } \\
\hline $17-20$ years & o & o & 19 & 19 & $<0.001$ \\
\hline 21 - 35 years & 5 & 5 & 48 & 48 & \\
\hline$>35$ years & 20 & 20 & 8 & 8 & \\
\hline \multicolumn{6}{|l|}{ Maternal Education } \\
\hline$<$ Senior High School & 0 & o & 12 & 12 & 0.033 \\
\hline$\geq$ Senior High School & 25 & 25 & 63 & 63 & \\
\hline \multicolumn{6}{|l|}{ Maternal Occupation } \\
\hline Others & o & o & 5 & 5 & 0.008 \\
\hline Housewife & 10 & 10 & 30 & 30 & \\
\hline Laborer / Farmer & 1 & 1 & 20 & 20 & \\
\hline Trader & 4 & 4 & 12 & 12 & \\
\hline Private Employee & 5 & 5 & 5 & 5 & \\
\hline \multirow{2}{*}{\multicolumn{6}{|c|}{ Number of Children }} \\
\hline & & & & & \\
\hline No children & $\mathrm{o}$ & o & 7 & 7 & $<0.001$ \\
\hline 1 child & 2 & 2 & 28 & 28 & \\
\hline 2 children & 11 & 11 & 37 & 37 & \\
\hline$\geq 3$ children & 12 & 12 & 3 & 3 & \\
\hline \multicolumn{6}{|l|}{ Maternal Labor } \\
\hline Intervention & o & o & 16 & 16 & 0.012 \\
\hline Normal & 25 & 25 & 59 & 59 & \\
\hline \multicolumn{6}{|l|}{ Age of Menarche } \\
\hline$<12$ years & 2 & 2 & 9 & 9 & 0.162 \\
\hline $12-15$ years & 16 & 16 & 57 & 57 & \\
\hline$>15$ years & 7 & 7 & 9 & 9 & \\
\hline \multicolumn{6}{|l|}{ Information Acquisition } \\
\hline Not yet & o & o & 74 & 74 & $<0.001$ \\
\hline Already & 25 & 25 & 1 & 1 & \\
\hline
\end{tabular}


Table 2. The result of bivariate analysis

\begin{tabular}{lcc}
\hline Independent Variable & OR & p \\
\hline Attitude & & \\
Norm & 3.14 & 0.007 \\
Perceived Behavior Control & 1.19 & 0.664 \\
Intention & 5.39 & 0.002 \\
\hline
\end{tabular}

\section{Path Analysis}

Figure 1 showed path analysis model on the implementation of theory of planned behavior (TPB) in LTCM participation among women of reproductive age. Figure 1 showed that LTCM participation was directly affected by intention to use LTCM. LTCM participation was indirectly affected by perceived behavior control through subjective norm, attitude, and intention. LTCM participation was indirectly affected by subjective norm through attitude and intention. LTCM participation was indirectly affected by attitude through intention. Figure 1 showed that TPB constructs affected women of reproductive age behavior to use long-term contraceptive method.

Table 3 showed the result of path analysis of the implementation of theory of planned behavior (TPB) in LTCM partici- pation among women of reproductive age. Table 3 showed that women participation in LTCM was directly and positively affected by intention $(b=2.07 ; 95 \% \mathrm{CI}=0.78$ to 3.36; $\mathrm{p}=0.002)$.

Table 3 showed that women participation in LTCM was indirectly and positively affected by $\mathrm{PBC}$ through subjective norm and intention.

Table 3 showed that women participation in LTCM was indirectly and positively affected by attitude through intention $(\mathrm{b}=$ $1.40 ; 95 \% \mathrm{CI}=0.41$ to $2.40 ; \mathrm{p}=0.006)$.

Table 3 showed that women participation in LTCM was indirectly and positively affected by subjective norm through attitude $(\mathrm{b}=1.17 ; 95 \% \mathrm{CI}=0.20$ to $2.13 ; \mathrm{p}=$ o.017).

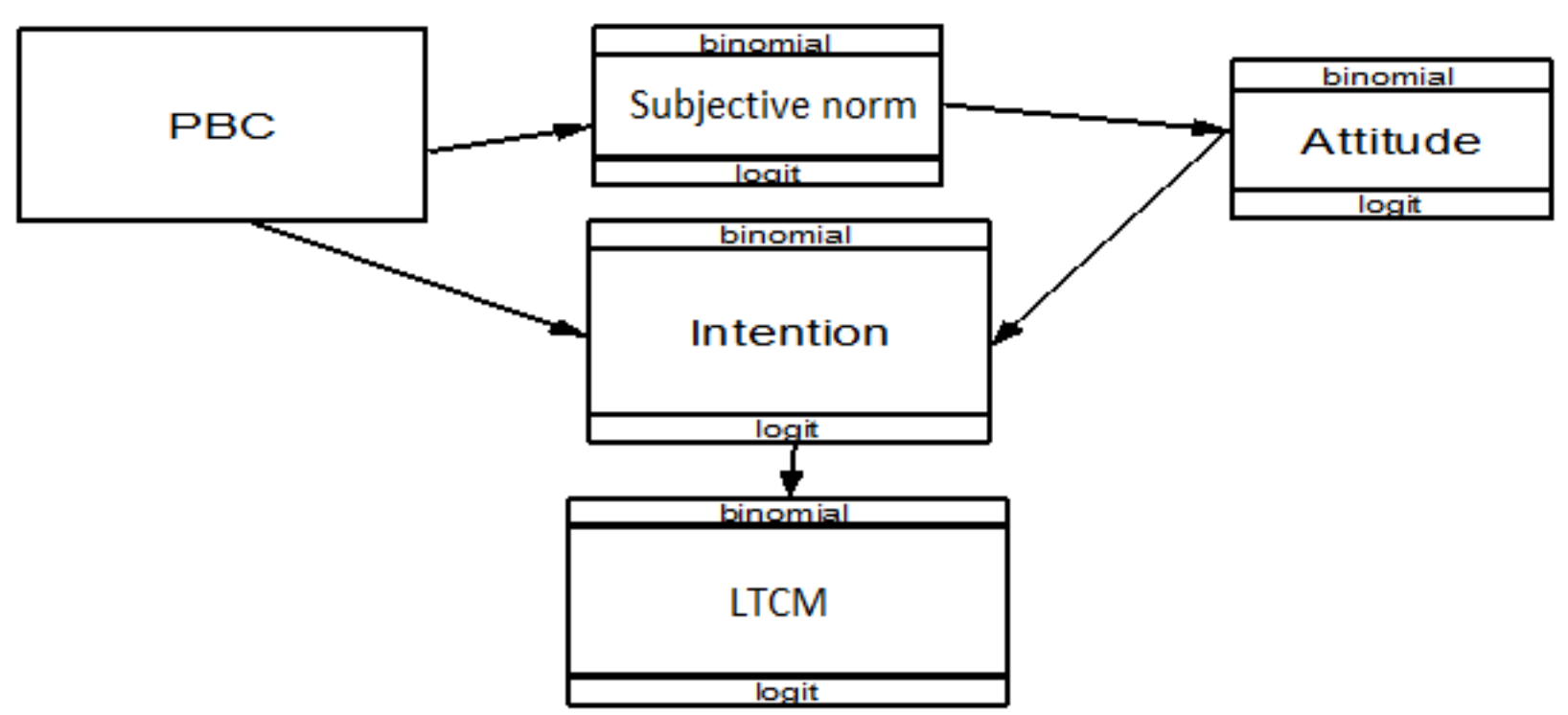

Figure 1. Path analysis model 
Journal of Health Promotion and Behavior (2016), 1(3): 172-180

https://doi.org/10.26911/thejhpb.2016.01.03.04

Table 3. The result of path analysis of the implementation of theory of planned behavior (TPB) in LTCM participation among women of reproductive age

\begin{tabular}{|c|c|c|c|c|c|c|}
\hline \multirow{2}{*}{\multicolumn{2}{|c|}{ Dependent variable }} & \multirow[b]{2}{*}{ Independent variables } & \multirow[b]{2}{*}{ b } & \multicolumn{2}{|c|}{$95 \% \mathrm{CI}$} & \multirow[b]{2}{*}{$\mathbf{p}$} \\
\hline & & & & $\begin{array}{l}\text { Lower } \\
\text { Limit }\end{array}$ & $\begin{array}{l}\text { Upper } \\
\text { Limit }\end{array}$ & \\
\hline \multicolumn{7}{|l|}{ Direct Effect } \\
\hline $\begin{array}{l}\text { Participation in LTCM } \\
\text { Indirect Effect }\end{array}$ & $\leftarrow$ & Intention (score $\geq 8$ ) & 2.07 & 0.78 & $3 \cdot 36$ & 0.002 \\
\hline Subjective Norm & $\leftarrow$ & PBC (score $\geq 7$ ) & 1.64 & 0.76 & 2.53 & $<0.001$ \\
\hline Intention & $\leftarrow$ & $\operatorname{PBC}($ score $\geq 7)$ & 1.22 & 0.32 & 2.12 & 0.008 \\
\hline & & Attitude (score $\geq 19$ ) & 1.40 & 0.41 & 2.40 & 0.006 \\
\hline Attitude & $\leftarrow$ & $\begin{array}{l}\text { Subjective Norm (score } \\
\geq 10 \text { ) }\end{array}$ & 1.17 & 0.20 & 2.13 & 0.017 \\
\hline \multicolumn{7}{|l|}{$\mathrm{N}$ Observation $=100$} \\
\hline
\end{tabular}

\section{DISCUSSION}

1. The correlation between attitude and intention in LTCM participation

The result of this study showed that there was a direct correlation which was significant between attitude and intention of women of reproductive age in becoming LTCM participants. It means that the better the attitude of women of reproductive age, the stronger the intention of women of reproductive age in becoming LTCM participants. This is in line with study conducted by Anggraeni (2015) which stated that women of reproductive age who have positive attitude about LTCM have 3 times greater chance in becoming LTCM participants than women of reproductive age who have negative attitude.

Attitude and belief indicate a potential of a person or known as self-determination. A tough individual is able to react authentically and purely and has the truth about stability and strength in herself. With this model, she is able to make decisions or determine attitudes based on autonomy rights. People who are persistentare aware of their limitations and weaknesses, but still rely on honest and pure decisions.

Attitudes, values, intentions and selfawareness can bring up to a behavior which comes from the correlation between know- ledge and social environment, through the source of information obtained. Therefore, the changes in views can improve to be more positive (Dignam, 1995). Attitude is an evaluative response. Response will only come up if the individual is faced with a stimulus that requires an individual reaction. Evaluative

Response is a reaction arises, which is expressed as an attitude based on the evaluation process in the individual who gives conclusions to the stimulus in the form of negative and positive values and crystallize as a potential reaction to the object of attitude (Azwar, 2011).

Attitude is determined by the individual's beliefs about the consequences of displaying a behavior (behavioral beliefs), which is considered based on the results of an evaluation of the consequences (outcome evaluation). These attitudes are believed to have a direct effect on intention to behave and they are associated with subjective norms and perceived behavioral control (Ajzen, 2005).

\section{The correlation between subjective norm and intention in LTCM partici- pation}

The result of this study showed that there was an indirect correlation which was nonsignificant between subjective norm and in- 
tention of women of reproductive age in becoming LTCM participants through attitude.It means that the better the subjective norm, the more positive the intention of women of reproductive age in becoming LTCM participants. Subjective norm is also affected by maternal trust on the norms around her, thus affecting attitude and maternal understanding.This result is in accordance with study conducted by Bamet and Persley (2004) and Ajzen (1992) which stated that intention (intention to use) is affected by perceived behavior control and subjective norm. Ajzen (2004) also stated that perceived behavior control has a great influence on intention (intention to use).

Subjective norms of reproductive age women have an important role in developing a positive attitude about LTCM, thus increasing the intention to participate in LTCM. Women of reproductive age who are aware that LTCM is an effective contraceptive model will be motivated to choose a contraceptive model: implants, IUDs, and female surgical sterilization. It is in accordance with the definition of LTCM, which is a long-term method of contraception which has a high effectiveness and continuity of use with low failure rates (National Population and Family Planning Board, 2009).

Subjective norm is assumed as a function of beliefs which are specifically approved or not approved by people to show a behavior. Beliefs which included in subjective norms are also called normative beliefs. An individual will intend to show a certain behavior if she perceives that people who are important think that she should do it (Ajzen, 2005). Other important people are spouses (husband and wife), friends, doctors, and others. They can be known by asking respondents to know whether they tend to agree or disagree with the behavior showed.
Subjective norm is affected by perceptions of social norms in the surrounding environment to behave based on the belief on socio-cultural norms and the motivation of closest people who encourage maternal intention to behave (Ajzen, 2005).

\section{The correlation between perceived behavior control and intention toward LTCM participation}

The result of this study showed that there was a direct correlation which was signifycant between perceived behavior control and intention of women of reproductive age in becoming LTCM participants through attitude. It means that the better the perceived behavior control, the stronger the intention of women of reproductive age in becoming LTCM participants. This is in line with a study conducted by Hartanto (2009) which stated that women of reproductive age who have high support from people around her will be easier to make decision to take LTCM than women of reproductive age who have low support. A husband has an important role as a head of household and a decision making, including decision making to select the contraceptives used by women of reproductive age.

If an individual has strong control beliefs about the existing factors that will facilitate a behavior, she has a high perception of being able to control a behavior. Otherwise, that individual will have a low perception of controlling a behavior if she has strong control beliefs about factors that inhibit behavior. This perception can reflect past experiences, anticipation of future situations, and attitudes towards influential norms around individuals (Ajzen, 2005).

A study conducted by Dharmmesta and Khasanah (1999) stated that the variables that affect individual intention to do something (intention touse) are attitude toward behavior variable, subjective norm, and perceived behavior control. 
Journal of Health Promotion and Behavior (2016), 1(3): 172-180

https://doi.org/10.26911/thejhpb.2016.01.03.04

\section{The correlation between perceived behavior control and LTCM partici- pation}

The result of this study showed that there was an indirect correlation which was significant between perceived behavior control and participation of women of reproductive age in LTCM through intention. It means that the better the perceived behavior control, the stronger the intention. As a result, the participation of women of reproductive age in LTCM is higher.

This perception of the ability to control behavior is defined as self-efficacy. These are beliefs that individual have or have not carried out particular behaviors. Individual has facilities and time to do that behavior and estimates her ability whether she has or does not have the ability to carry out the behavior. This condition is named "perception of control ability" (perceived behavioral control) (Ajzen, 2005).

If an individual has strong control beliefs about the existing factors that will facilitate a behavior, she has a high perception of being able to control a behavior. Otherwise, that individual will have a low perception of controlling a behavior if she has strong control beliefs about factors that inhibit behavior. In the context ot study about the participation of women of reproductive age in LTCM, the perceived behavior control variable can be measured by indicators of support from spouses, families, economic abilities, and availability of health facilities.

Husband's support often dominates in the family. Even though the wife does not have the intention to do a behavior, the wife will do a behavior due to the husband agreement. It is also related to the participation in LTCM; if the husband gives optimal support, the women of reproductive age who does not intend to take the LTCM at first can immediately obey her husband's direction.

\section{The correlation between intention and LTCM participation}

The result of this study showed that there was a direct correlation which was significant between intention and participation of women of reproductive age in LTCM. It means that the stronger the intention of women of reproductive age, the higher the participation of women of reproductive age.

Intention to do a behavior (intention) is the tendency of someone to choose to do or not do a job. The strong and weak intentions are determined by how far the individual has positive attitude towards a particular behavior, and how far she chooses to do behavior (Eng and Parker, 2002). The women of reproductive age who have had the intention and plan to take the LTCM have a big chance in on the real participation inLTCM.

According to the TPB concept, a person can act based on his intention only if she has control over his behavior. This theory not only emphasizes the rationality of human behavior, but also on the belief that behavioral targets are under the control of the individual's consciousness. Furthermore, that behavior does not only depend on one's intentions, but also on other factors which are not under the control of the individual such as the availability of resources and opportunities to display these behaviors (Ajzen, 2005). There is a direct and indirect correlation between the implementation of Theory of Planned Behavior in the participation of women of reproductive age in LTCM at Bagor Community Health Center, Nganjuk.

\footnotetext{
REFERENCE

Ajzen I (2005). Attitudes, personality, and Behavior $\left(2^{\text {nd }}\right.$ ed). Berkshire: Open University Press.
} 
Anggraeni P (2015). Determinan penggunaan MKJP di wilayah kerja puskesmas pamulang tahun 2014 (Determination of the use of MKJP in the work area Pamulang health center 2014). Tesis. Universitas Islam Negeri Syarif Hidayatullah. Retrieved from http://repository.uinjkt.ac.id/dspace/bitstream/1 23456789/28910/1/PUTRI\%20ANG GRAENI-FKIK.pdf

Azwar S (2011). Sikap manusia, teori dan pengukurannya, edisi kedua (Human attitudes, theories and measurements, second edition). Yogyakarta: Pustaka Pelajar.

Central Bureau of Statistic (2012). Penduduk Indonesia menurut propinsi 2010 (Population of Indonesia by province 2010). Retrieved https://www.bps.go.id/publication/2010/10/04/d8ad1 f6168e396f4b7be5501/pendudukindonesia-menurut-provinsi-dankab-kota-sp-2010.html

BKKBN (2007). Keluarga berencana dan kontrasepsi; cetakan ke-5 (Family planning and contraception; 5th mould). Jakarta. BKKBN
Dignam (1995). Understanding intimacy as experienced women. Health Care Women Int, 16 (5): 477-485. https://doi.org/10.1080/07399339509516200

Dharmmesta BS, Khasanah U (1999). Theory of planned behavior: An application to transport service consumer. Gajah Mada International Journal of Business. 1(1). Retrieved from http://i-lib.ugm.ac.id/jurnal/detail.php?dataId $=664$

Eng E, Parker E (2002). Natural helper models to enhance a community's health and competence. In R J. Diclemente, R. A. Crosby, \& M. C. Kegler (Eds.), Emerging Theories in Health Promotion Practice and Research: Strategies for Improving Public Healt. San Francisco, CA: Jossey-Bass.

Hartanto H (2009). Keluarga Berencana dan Kontrasepsi (Family planning and contraception). Jakarta: Pustaka Sinar Harapan.

Murti B (2013). Desain dan besar sampel untuk penelitian kuantitatif dan kualitatif (Design and large samples for quantitative and qualitative research). Yogyakarta: UGM Press. 